


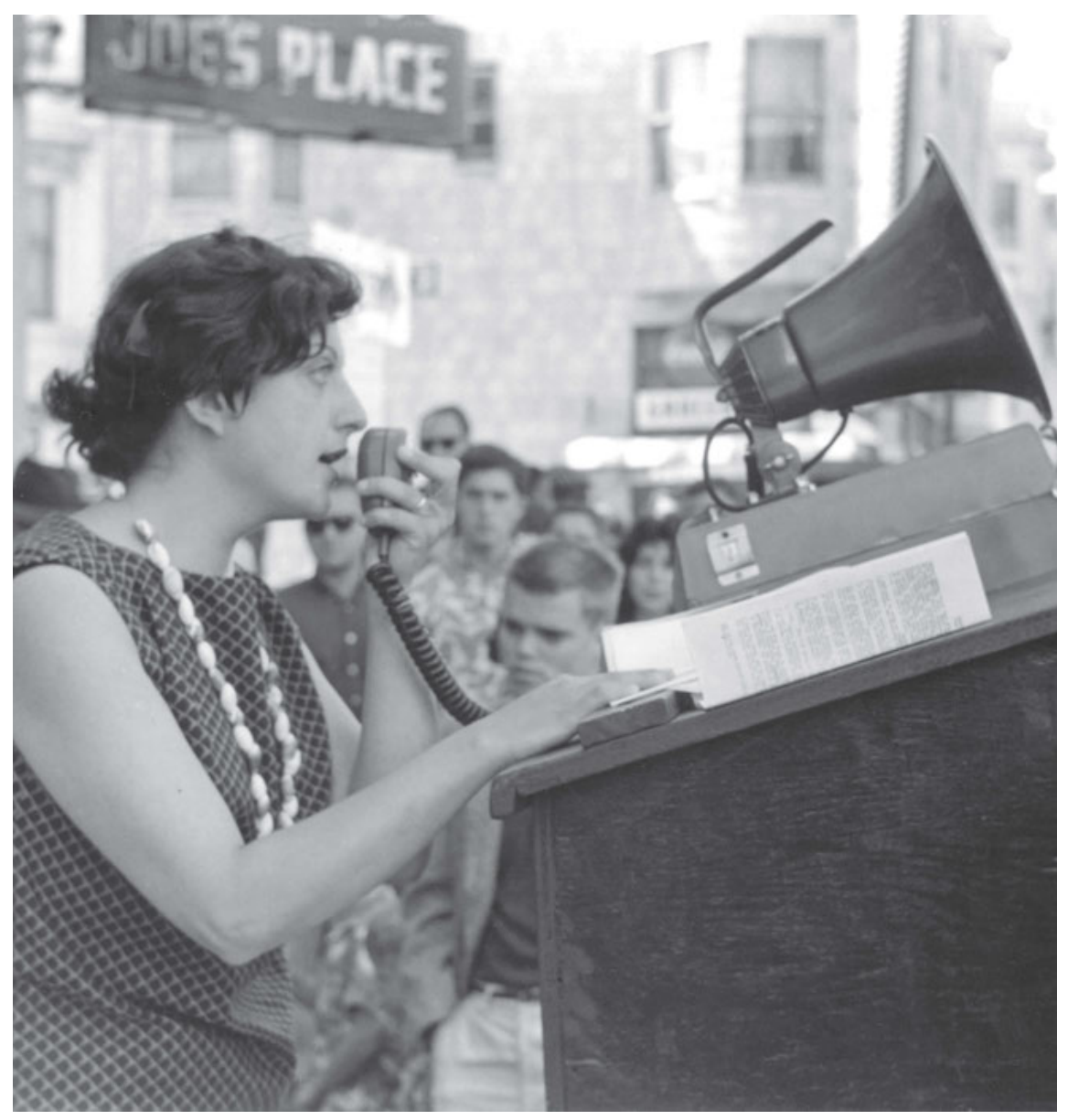


ruth weiss: Beat Poetry, Jazz, Art 


\section{American Frictions}

\section{Editors}

Carsten Junker

Julia Roth

Darieck Scott

Editorial Board

Arjun Appadurai, New York University

Mita Banerjee, University of Mainz

Tomasz Basiuk, University of Warsaw

Isabel Caldeira, University of Coimbra

\section{Volume 3}


Estíbaliz Encarnación-Pinedo, Thomas Antonic ruth weiss

Beat Poetry, Jazz, Art 
ISBN 978-3-11-069442-0

e-ISBN (PDF) 978-3-11-069455-0

e-ISBN (EPUB) 978-3-11-069464-2

ISSN 2698-5349

Library of Congress Control Number: 2021938518

Bibliographic information published by the Deutsche Nationalbibliothek

The Deutsche Nationalbibliothek lists this publication in the Deutsche Nationalbibliografie; detailed bibliographic data are available on the Internet at http://dnb.dnb.de.

(C) 2021 Walter de Gruyter GmbH, Berlin/Boston Frontispiece: ruth weiss 1959, (C) C. R. Snyder

Printing and binding: CPI books $\mathrm{GmbH}$, Leck

www.degruyter.com 